\title{
PERAN PERTANIAN URBAN PADA KESEJAHTERAAN PETANI MUSLIM PADA EMPAT KELOMPOK TANI DI SURABAYA DITINJAU DARI PERSPEKTIF ISLAM ${ }^{1)}$
}

\author{
Trisna Setia Permana \\ Program Studi S1 Ekonomi Islam-Fakultas Ekonomi dan Bisnis-Universitas Airlangga \\ Email : trisnasetiapermana@gmail.com \\ Moh. Qudsi Fauzy \\ Departemen Ekonomi Syariah-Fakultas Ekonomi dan Bisnis-Universitas Airlangga \\ Email : qudsifauzy1@gmail.com
}

\begin{abstract}
:
This study aimed to describe the role of urban farming in the welfare of the Muslim farmers in four farmer groups in Surabaya from the perspective of Islam. This study used descriptive qualitative approach with case study strategy. The data authenticity technique using construct validity tactics with multiple sources of evidence. The analysis technique using pattern matching logic. The results showed the positive role of urban farming in the material welfare, namely: the creation of job opportunities and self-employment, the creation of small businesses in the agricultural sector and the informal sector, and increase the income of the four members of farmer groups; whereas the non-material welfare, namely: produce farmed commodities and processed products that is classified as halal, income which does not contain usury, implementing the principles of honesty and fairness principles in marketing, as well as undertake community development activities such as counseling and training.
\end{abstract}

Keywords: Urban Farming, Urban Agriculture, Farmer Group, Welfare in the Perspective of Islam

\section{PENDAHULUAN}

Sumber daya tanah merupakan

peningkatan konsumsi per kapita. sumber daya alam yang sangat penting Penggunaan lahan harus dilakukan untuk kelangsungan hidup manusia karena diperlukan dalam setiap kegiatan seperti untuk pertanian, daerah industri, daerah pemukiman, jalan untuk transportasi, daerah rekreasi atau daerahdaerah yang dipelihara kondisi alamnya untuk tujuan ilmiah. Arsyad (1989:207) mengatakan bahwa lahan adalah lingkungan fisik yang terdiri atas iklim, relief, tanah, air dan vegetasi serta benda yang ada di atasnya sepanjang ada pengaruh terhadap penggunaannya.

Rustiadi dalam Siswanto (2006:1) mengatakan bahwa permintaan sumber daya lahan terus meningkat akibat tekanan pertambahan penduduk dan dengan sangat bijaksana demi mengatasi masalah tersebut sehingga dapat menjamin kelangsungan hidup di masa mendatang.

Badan Pertanahan Nasional dalam Primartantyo (2011) menyatakan bahwa selama dua tahun terakhir melakukan inventarisasi tentang pemanfaatan lahan di Indonesia. Hasilnya, ada 7,3 juta hektar lahan pertanian milik masyarakat yang tidak digarap dan 4,96 juta hektar lahan kosong yang tidak digunakan milik Kementerian Kehutanan.

Permasalahan ini pun tak luput dari pembahasan dalam lingkup Islam. Islam mencintai manusia untuk meluaskan 
Permana, et al/Jurnal Ekonomi Syariah Teori dan Terapan Vol. 3 No. 12 Desember 2016: 945-959; PERAN PERTANIAN URBAN PADA KESEJAHTERAAN PETANI MUSLIM PADA EMPAT KELOMPOK TANI DI SURABAYA DITINJAU DARI PERSPEKTIF ISLAM

bagiannya dalam menggarap dan bertebaran di muka bumi serta menghidupkan tanah yang mati sehingga kekayaan mereka banyak dan menjadi kuat. Islam menyukai pemeluknya memperhatikan tanah yang mati lalu menghidupkannya,

menggali kebaikannya dan memanfaatkan keberkahannya". Sebagaimana sabda Rasulullah SAW berikut.

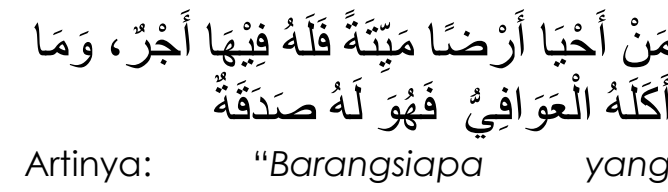
menghidupkan tanah yang mati, maka di sana ia akan memperoleh pahala dan tanaman yang dimakan binatang kecil (seperti burung atau binatang liar), maka hal itu menjadi sedekah baginya." (HR. Darimiy dan Ahmad dan dishahihkan oleh Syaikh al-Albani dalam al-Irwaa' [4/6]) (Musa, 2013).

Pembahasan tentang tanah atau lahan yang tidak dimanfaatkan agar dimanfaatkan, misalnya untuk lahan perkebunan dan pertanian, juga disebutkan dalam Alquran. Bahwasanya Allah SWT selalu menghidupkan tanah yang mati jika manusia mau merawatnya dan membuat tanah itu subur sebagaimana penjelasan dalam Surat Yāsīn:33 berikut.

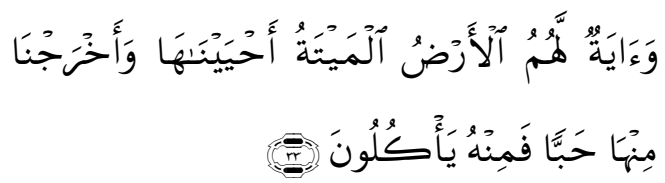

Artinya: "33. Dan suatu tanda (kekuasaan Allah yang besar) bagi mereka adalah bumi yang mati. Kami hidupkan bumi itu dan Kami keluarkan daripadanya biji-bijian, maka dari biji-bijian itu mereka makan." (QS Yāsīn:33) (Kemenag, 2009:709).
Saat ini program bertani di tengah kota sedang gencar dilakukan. Bertani di tengah kota selain menambah luasan lahan hijau, juga dapat menjadikan penghasilan tambahan bagi pelakunya. Hampir setiap lahan kosong digarap warganya menjadi kebun sayuran, buahbuahan, dan tanaman obat keluarga. Dinas Pertanian Surabaya juga menggalakkan program serupa dengan sebutan Urban Farming (Pertanian Urban atau Pertanian Perkotaan).

$$
\text { Santoso dan Rini }
$$

menjelaskan bahwa sasaran kegiatan Program Pertanian Perkotaan, yang merupakan bagian dari Program Penanggulangan Kemiskinan, adalah kelvarga miskin di wilayah Kota Surabaya yang tersebar di 31 kecamatan. SKPD pada tahun 2009 di bawah Pemerintah Kota Surabaya yang melaksanakan kegiatan ini adalah Dinas Pertanian dan Kantor Ketahanan Pangan. Sejak tahun 2010 leading sector kegiatan ini adalah Dinas Pertanian. Tujuan utama kegiatan ini adalah meningkatkan ketahanan pangan kelvarga miskin melalui pemenuhan ketersediaan gizi keluarga miskin secara mandiri dengan memanfaatkan pekarangan untuk kegiatan budidaya. Ada dua jenis komoditi yang dikembangkan dalam kegiatan ini yaitu perikanan (budidaya ikan) dan pertanian melalui budidaya tanaman hortikultura. Bantuan yang diberikan berupa paket benih ikan, pakan, dan media (drum, tong, dan kolam terpal) untuk jenis 
Permana, et al/Jurnal Ekonomi Syariah Teori dan Terapan Vol. 3 No. 12 Desember 2016: 945-959; PERAN PERTANIAN URBAN PADA KESEJAHTERAAN PETANI MUSLIM PADA EMPAT KELOMPOK TANI DI SURABAYA DITINJAU DARI PERSPEKTIF ISLAM

komoditi perikanan; sedangkan bantuan tanaman hortikultura berupa paket benih terong, cabe, sawi, bayam, kangkung serta kelengkapannya seperti pupuk, media tanam dan polybag.

Terdapat tren positif dari kegiatan pertanian urban yaitu sebagian penerima tidak hanya memanfaatkan bantuan kegiatan untuk memenuhi kebutuhan sehari-hari, namun bisa menjual hasil yang dibudidayakan untuk memperoleh pendapatan tambahan. Hal ini terutama dilaksanakan oleh penerima bantuan yang mengusahakan budidaya secara berkelompok. Berdasarkan keterangan tersebut, kegiatan pertanian urban dapat dikembangkan di masa mendatang untuk meningkatkan ekonomi keluarga dengan adanya pendapatan tambahan (Santoso dan Rini, 2014:5).

Data yang diperoleh dari Dinas Pertanian Kota Surabaya menunjukkan terdapat 57 kelompok tani dan 35 kelompok tani bidang perikanan di Surabaya. Menurut keterangan dari Kepala Seksi Tanaman Pangan dan Holtikultura Dinas Pertanian Kota Surabaya, saat ini banyak kelompok tani holtikultura terutama yang menerima bantuan untuk memulai kegiatan Urban Farming sudah tidak lagi melakukan kegiatan budidaya, tetapi hanya melakukan kegiatan pengolahan untuk memroduksi produk-produk pangan sehingga esensi dari kegiatan pertanian urban menjadi hilang.
Ekonomi Islam menghendaki kesejahteraan itu juga mencakup keseluruhan unsur materi dan non materi (psikis). Hal ini disebabkan kepuasan manusia itu terletak pada unsur-unsur non materi. Kesejahteraan yang optimal dapat tercapai apabila kecerdasan material dikontrol oleh kecerdasan spiritual mulai dari cara memperolehnya sampai kepada membelanjakannya (Purwana, 2014). Kecerdasan Islami merupakan fungsi dari kecerdasan material dan kecerdasan spiritual. Kecerdasan Islami dapat dicapai apabila hal-hal sebagai berikut dilakukan, yakni: benda yang dimiliki diperoleh dengan cara halal dan baik, bertujuan untuk ibadah, kualitas lebih dipentingkan daripada kuantitas, dan penggunaannya sesuai syariah (Aedy, 2011:113).

Kenyataannya, tidak semua manusia memiliki kecerdasan spirtual sebagaimana yang dijelaskan. Adapun ciri-ciri manusia yang memiliki ciri-ciri kecerdasan adalah: setia dan taat kepada Allah SWT (habl min Allah), setia dan konsisten memberikan manfaat atau pelayanan terbaik kepada sesama manusia (habl min al-nās), dan setia dan konsisten dengan pemelihara alam dan lingkungan yang seimbang (habl min al'ālamin) (Aedy, 2011:113-114).

Berdasarkan latar belakang yang telah dijelaskan, maka peneliti melakukan penelitian mengenai bagaimana peran pertanian urban dalam meningkatkan kesejahteraan petani muslim di Surabaya 
Permana, et al/Jurnal Ekonomi Syariah Teori dan Terapan Vol. 3 No. 12 Desember 2016: 945-959; PERAN PERTANIAN URBAN PADA KESEJAHTERAAN PETANI MUSLIM PADA EMPAT KELOMPOK TANI DI SURABAYA DITINJAU DARI PERSPEKTIF ISLAM

ditinjau dari perspektif Islam. Judul yang digunakan yakni Peran Pertanian Urban Pada Kesejahteraan Petani Muslim Pada Empat Kelompok Tani di Surabaya Ditinjau dari Perspektif Islam.

\section{LANDASAN TEORI}

Pertanian urban atau pertanian prekotaan memiliki banyak penjelasan. Smit (2001:1-3) menjelaskan dengan lengkap mengenai pertanian urban dan dapat disimpulkan bahwa pertanian urban adalah makanan dan bahan bakar tumbuh ditengah-tengah aktivitas perkotaan atau kota, untuk dipasarkan dan sering juga diolah lalu dipasarkan. Hal ini termasuk budidaya perikanan dalam tangki, kolam, sungai dan teluk/pantai; serta sayuran dan tanaman lainnya ditanam di atap, di halaman belakang, lahan kosong kawasan industri, sepanjang kanal, di lapangan perkantoran, di pinggir jalan dan di banyak peternakan kecil di pinggiran kota.

Penjelasan Smit tersebut menyatakan bahwa pertanian urban mencakup budidaya hewan dan tanaman. Alquran menjelaskan tentang budidaya hewan dan tanaman sebagai salah satu sumber rezeki bagi manusia pada surat AlAn'aam:141-142 berikut.

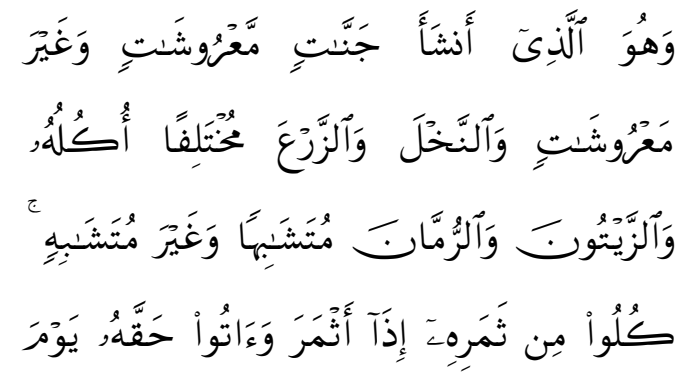

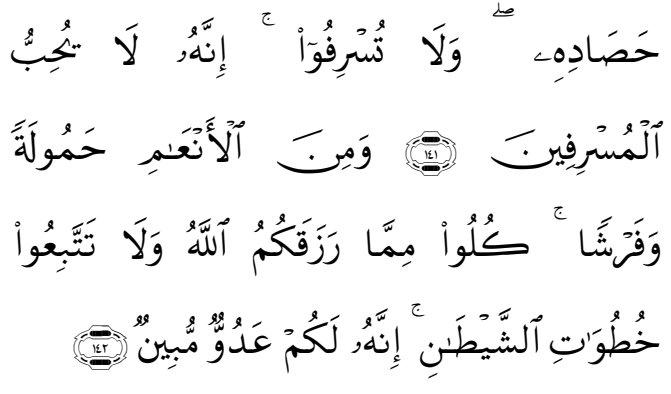

Artinya: "141. Dan Dialah yang menjadikan kebun-kebun yang berjunjung dan yang tidak berjunjung, pohon korma, tanaman-tanaman yang bermacam-macam buahnya, zaitun dan delima yang serupa (bentuk dan warnanya) dan tidak sama (rasanya). Makanlah dari buahnya (yang bermacam-macam itu) bila dia berbuah, dan tunaikanlah haknya di hari memetik hasilnya (dengan dikeluarkan zakatnya), dan janganlah kamu berlebih-lebihan. Sesungguhnya Allah tidak menyukai orang-orang yang berlebih-lebihan. 142. Dan di antara binatang ternak itu ada yang dijadikan pengangkut dan ada yang untuk disembelih. Makanlah dari rezeki yang telah diberikan Allah kepadamu, dan janganlah kamu mengikuti langkahlangkah syaitan. Sesungguhnya syaitan itu musuh yang nyata bagimu." (QS An'aam:141-142) (Kemenag, 2009:212).

Kaufman dan Martin (2000:84-85) dalam penelitiannya menyimpulkan bahwa pertanian urban memiliki manfaat positif termasuk dalam bidang ekonomi utamanya dalam aspek kewirausahaan. Manfaat yang dimaksud yaitu: (1) keberagaman pasar usaha pertanian urban yang mendukung proyek pertanian urban, (2) dukungan pemasaran produk pertanian urban oleh pejabat lokal, pemerintah, kelompok masyarakat, dan yayasan lokal, (3) masyarakat yang tinggal di dekat tempat usaha pengembangan makanan umumnya 
Permana, et al/Jurnal Ekonomi Syariah Teori dan Terapan Vol. 3 No. 12 Desember 2016: 945-959; PERAN PERTANIAN URBAN PADA KESEJAHTERAAN PETANI MUSLIM PADA EMPAT KELOMPOK TANI DI SURABAYA DITINJAU DARI PERSPEKTIF ISLAM

bertindak positif untuk mengembangkan lingkungan mereka, (4) operasi pasar untuk pertanian urban dari pemerintah dan yayasan dapat menyediakan modal kerja untuk tahap awal, dan (5) sejumlah proyek kewirausahaan pertanian urban mulai menghasilkan keuntungan serta selebihnya memberikan manfaat sosial, estetika, kesehatan, serta pembangunan dan pemberdayaan masyarakat.

Veenhuizen dan Danso (2007:28) mengatakan bahwa dampak ekonomi pertanian urban terbagi menjadi tiga tingkatan, yaitu tingkat rumah tangga, tingkat kota, dan tingkat makro. Dampak ekonomi pertanian urban pada tingkat rumah tangga yaitu menciptakan pelvang wirausaha, adanya pendapatan dari pengolahan, adanya penjualan dari kelebihan yang ada, menghemat pengeluaran untuk makanan dan kesehatan, dan sebagai pengganti barang ekonomis lain.

Moustier dalam Veenhuizen dan Danso (2007:30) memberikan indikator ekonomi sebagai parameter dampak pertanian urban pada tingkat rumah tangga, yaitu ketenagakerjaan (penduduk yang terlibat), pendapatan dan distribusi pendapatan, kontribusi terhadap pangan pada rumah tangga, nilai tambah, kontribusi relatif terhadap pasokan pangan perkotaan, dan pangsa pasar.

Kesejahteraan dalam pandangan Islam tentu saja berbeda secara mendasar dengan pengertian kesejahteraan dalam ekonomi konvensional yang sekuler dan materialistik. Ekonomi Islam yang merupakan salah satu bagian dari Syariat Islam, tujuannya tentu tidak lepas dari tujuan utama Syariat Islam. Tujuan utama ekonomi Islam adalah merealisasikan tujuan manusia untuk mencapai kebahagiaan dunia dan akhirat (falah), serta kehidupan yang baik dan terhormat (al-hayah al-tayyibah) (Anto, 2003:7).

Menurut Purbaya (2015:12 - 13) terdapat tujuh hal yang menjadi tujuan Ekonomi Islam. Secara terperinci tujuan ekonomi Islam dapat dijelaskan sebagai berikut.

1. Kesejahteraan ekonomi adalah tujuan ekonomi yang terpenting. Kesejahteraan ini mencakup kesejahteraan individu, masyarakat dan negara.

2. Tercukupinya kebutuhan dasar manusia, meliputi makan, minum, pakaian, tempat tinggal, kesehatan, pendidikan, keamanan serta sistem negara yang menjamin terlaksananya kecukupan kebutuhan dasar secara adil dibidang ekonomi.

3. Penggunaan sumberdaya secara optimal, efisien, efektif, hemat dan tidak mubazir.

4. Distribusi harta, kekayaan, pendapatan, dan hasil pembangunan secara adil dan merata.

5. Menjamin kebebasan individu.

6. Kesamaan hak dan peluang. 
Permana, et al/Jurnal Ekonomi Syariah Teori dan Terapan Vol. 3 No. 12 Desember 2016: 945-959; PERAN PERTANIAN URBAN PADA KESEJAHTERAAN PETANI MUSLIM PADA EMPAT KELOMPOK TANI DI SURABAYA DITINJAU DARI PERSPEKTIF ISLAM

7. Kerjasama dan keadilan.

Kecerdasan Islami merupakan fungsi dari kecerdasan material dan kecerdasan spiritual. Kecerdasan Islami dapat dicapai apabila hal-hal sebagai berikut dilakukan, yakni: benda yang dimiliki diperoleh dengan cara halal dan baik, bertujuan untuk ibadah, kualitas lebih dipentingkan daripada kuantitas, dan penggunaannya sesuai syariat (Aedy, 2011:113).

Kenyataannya, tidak semua manusia memiliki kecerdasan spirtual sebagaimana yang dijelaskan. Adapun ciri-ciri manusia yang memiliki ciri-ciri kecerdasan adalah: setia dan taat kepada Allah SWT (habl min Allah), setia dan konsisten memberikan manfaat atau pelayanan terbaik kepada sesama manusia (habl min al-nās), dan setia dan konsisten dengan pemelihara alam dan lingkungan yang seimbang (habl min al'ālamīn) (Aedy, 2011:113-114).

Proposisi

Proposisi dalam penelitian ini adalah pertanian urban berperan positif pada perekonomian kelompok tani muslim di Surabaya dalam perspektif ekonomi mikro Islam.

\section{METODE PENELITIAN}

Penelitian ini menggunakan pendekatan penelitian kualitatif deskriptif dengan strategi studi kasus yang merupakan strategi yang lebih cocok bila pokok pertanyaan suatu penelitian berkenaan dengan pertanyaan "bagaimana" atau "mengapa", bila peneliti hanya memiliki sedikit peluang untuk mengontrol peristiwa-peristiwa yang akan diselidiki, dan bilamana fokus penelitiannya terletak pada fenomena kontemporer (masa kini) didalam konteks kehidupan nyata (Yin, 2009:13). Desain penelitian untuk studi kasus sebagai berikut.

1. Pertanyaan penelitian

Bagaimana peran pertanian urban pada kesejahteraan petani muslim pada empat kelompok tani di Surabaya ditinjau dari perspektif Islam?

2. Unit analisis

Unit analisis penelitian ini adalah empat kelompok tani di Surabaya

3. Logika yang mengaitkan data dengan proposisi

Pendekatan dengan penjodohan pola mengaitkan beberapa informasi kasus yang sama dengan proposisi yang digunakan.

4. Kriteria interpretasi temuan

Penelitian ini membangun validitas dengan menggunakan bukti data dari berbagai sumber untuk dibandingkan, yaitu hasil wawancara, observasi, dan dokumentasi.

\section{Ruang Lingkup penelitian}

Ruang lingkup dalam penelitian ini yaitu meliputi empat kelompok tani di Surabaya.

\section{Sumber dan Jenis Data}

Sumber data yang dikumpulkan oleh peneliti, yaitu:

1. Data primer, yaitu data yang diperoleh melalui wawancara dan 
Permana, et al/Jurnal Ekonomi Syariah Teori dan Terapan Vol. 3 No. 12 Desember 2016: 945-959; PERAN PERTANIAN URBAN PADA KESEJAHTERAAN PETANI MUSLIM PADA EMPAT KELOMPOK TANI DI SURABAYA DITINJAU DARI PERSPEKTIF ISLAM

observasi. Hasil wawancara dari informan kunci yang memahami dan mempunyai kaitan dengan permasalahan yang sedang diteliti. Informan kunci yaitu pengurus kelompok tani muslim yang melaksanakan pertanian urban.

2. Data sekunder, yaitu berupa arsip, rekaman, foto, jurnal, maupun artikel yang berkaitan dengan topik penelitian.

Penelitian ini menggunakan teknik purposive informan dalam mendapatkan informan. Kriteria penentuan kelompok tani yang diteliti sebagai berikut.

1. Kelompok tani yang telah melaksanakan pertanian urban dalam jangka waktu lima tahun atau lebih.

2. Kelompok tani yang masih melakukan kegiatan budidaya.

3. Kelompok tani yang memiliki struktur kepengurusan.

4. Kelompok tani yang memiliki pengurus dan anggota yang beragama Islam. Kriteria informan dalam penelitian ini sebagai berikut.

a. Pengurus atau anggota kelompok yang masih aktif dan terlibat dalam kegiatan kelompok tani yang bersangkutan.

b. Pengurus atau anggota kelompok harus menguasai atau memahami tentang apa saja kegiatan yang dilakukan oleh kelompok tani yang bersangkutan.

Teknik Pengumpulan Data
Penelitian ini menggunakan teknik wawancara semi terstruktur. Peneliti sudah menyiapkan topik dan daftar pemandu pertanyaan namun panduan wawancara yang telah disiapkan harus diikuti dengan pertanyaan tambahan untuk menggali lebih jauh jawaban informan.

\section{Teknik Keabsahan Data}

Penelitian ini menggunakan construct validity dengan taktik multiple sources of evidence yaitu mengumpulkan data dari berbagai sumber untuk dibandingkan (Yin, 2009:41-42). Data yang dimaksud berupa hasil wawancara, observasi, dan dokumentasi dari empat kelompok tani yang diteliti.

\section{Teknik Analisis}

Strategi umum yang digunakan yakni mendasarkan pada proposisi teoritis, yaitu mengikuti proposisi teoritis yang menuntun studi kasus (Yin, 2009:130).

Teknik analisis dalam penelitian ini menggunakan logika penjodohan pola, yaitu logika yang membandingkan antara pola empiris dengan pola yang telah diprediksikan. Validitas hasil penelitian studi kasus akan semakin kuat jika polapola tersebut saling bertepatan (Yin, 2009:136).

\section{HASIL DAN PEMBAHASAN}

\section{Kelompok Tani Pertama}

Kelompok pertama dibentuk pada tahun 2008 oleh inisiatif salah seorang warga di Kelurahan Kejawan Putih Tambak, Kecamatan Mulyosari. Masalah kemiskinan dan rendahnya tingkat 
Permana, et al/Jurnal Ekonomi Syariah Teori dan Terapan Vol. 3 No. 12 Desember 2016: 945-959; PERAN PERTANIAN URBAN PADA KESEJAHTERAAN PETANI MUSLIM PADA EMPAT KELOMPOK TANI DI SURABAYA DITINJAU DARI PERSPEKTIF ISLAM

pendidikan warga setempat menjadi latar belakang pembentukan kelompok tani.

Struktur Kepengurusan kelompok tani pertama terdiri dari Ketua, Sekretaris, dan Bendahara yang menangani Divisi Produksi. Anggota kelompok sebanyak 48 orang terbagi ke dalam bagian-bagian pada Divisi Produksi.
Komoditas utama kelompok tani pertama adalah buah markisa. Anggota pengembangbiak menanam markisa di rumah masing-masing dan buah markisa yang dihasilkan bisa dijual kepada anggota bagian produksi sirup, selai, dan kue kering sebagai bahan baku.

Hasil penelitian pada kelompok tani pertama disajikan pada Tabel 1.

Tabel 1.

Hasil Penelitian Pada Kelompok Tani Pertama

\begin{tabular}{|c|c|c|}
\hline \multicolumn{2}{|r|}{ Indikator } & Keterangan \\
\hline \multirow{3}{*}{$\begin{array}{l}\text { Kewirausahaan } \\
\text { dan kesempatan } \\
\text { kerja }\end{array}$} & Memanfaatkan peluang & adanya keberadaan warga lansia yang juga pensiunan \\
\hline & Memanfaatkan kemampuan & mengolah buah markisa menjadi produk olahan \\
\hline & Sebagai bentuk pekerjaan & sebagai bentuk pekerjaan sampingan \\
\hline \multirow{3}{*}{ Produksi } & $\begin{array}{l}\text { Usaha dan pemanfaatan } \\
\text { sumber daya }\end{array}$ & $\begin{array}{l}\text { usaha fisik budidaya markisa dan pengolahan menjadi } \\
\text { produk baru berupa sirup, kue kering, dan selai }\end{array}$ \\
\hline & Produksi barang halal & produk tergolong halal \\
\hline & Peningkatan nilai guna & $\begin{array}{l}\text { pengolahan buah markisa menjadi produk olahan yang } \\
\text { bernilai jual lebih tinggi }\end{array}$ \\
\hline \multirow{3}{*}{ Pemasaran } & Adanya proses pemasaran & $\begin{array}{l}\text { penjualan langsung kepada konsumen dan penjualan } \\
\text { tidak langsung melalui koperasi di lingkungan kampus }\end{array}$ \\
\hline & Implementasi prinsip kejujuran & $\begin{array}{l}\text { menjual buah markisa yang bagus saja; keterbukaan } \\
\text { informasi mengenai produk sirup markisa yang } \\
\text { menggunakan pengawet dan belum mendapat nomor } \\
\text { PIRT }\end{array}$ \\
\hline & Implementasi prinsip keadilan & $\begin{array}{l}\text { penentuan harga beli buah markisa yang sesuai harga } \\
\text { pasar dan penjualan sirup markisa yang sesuai takaran }\end{array}$ \\
\hline \multirow{3}{*}{ Pendapatan } & $\begin{array}{l}\text { Adanya pendapatan yang } \\
\text { diperoleh }\end{array}$ & $\begin{array}{l}\text { dari penjualan buah markisa kepada bagian pengolahan } \\
\text { dan penjualan sirup markisa }\end{array}$ \\
\hline & Pemenuhan kebutuhan & $\begin{array}{l}\text { belum memenuhi; pendapatan dari budidaya markisa } \\
\text { dan penjualan sirup markisa di bawah nilai UMK Surabaya }\end{array}$ \\
\hline & Tidak terdapat riba & pendapatan tidak mengandung riba \\
\hline \multirow{2}{*}{$\begin{array}{l}\text { Kepedulian } \\
\text { sosial-ekonomi }\end{array}$} & Zakat & ada pengeluaran zakat pada tingkat kelompok \\
\hline & Kegiatan sosial & pelatihan di berbagai tempat \\
\hline
\end{tabular}

Sumber: hasil penelitian, 2016 (diolah)

\section{Kelompok Tani Kedua}

Kelompok tani kedua yang dibentuk sejak 20 tahun lalu terdiri dari beberapa unit kelompok tani yang terbagi dalam setiap RW di Kelurahan Made, Kecamatan Sambikerep. Latar belakang pembentukan gapoktan tersebut adalah belum adanya wadah bagi petani setempat untuk bekerjasama baik antara petani di kelurahan maupun dengan pihak luar.
Tujuan dibentuknya gapoktan ini adalah mewujudkan kesejahteraan petani. Kelompok tani juga dibentuk agar memudahkan pelaksanaan penyuluhan metode pertanian yang rutin dilakukan supaya lebih terorganisir dan lebih menghemat waktu dalam penyampaian informasi.

Produk unggulan kelompok tani kedua adalah cabai. Selain karena harga jualnya yang tergolong tinggi, juga sebagian besar petani di Kelurahan Made 
Permana, et al/Jurnal Ekonomi Syariah Teori dan Terapan Vol. 3 No. 12 Desember 2016: 945-959; PERAN PERTANIAN URBAN PADA KESEJAHTERAAN PETANI MUSLIM PADA EMPAT KELOMPOK TANI DI SURABAYA DITINJAU DARI PERSPEKTIF ISLAM

telah membudidayakan cabai sejak lama sehingga sudah menggunakan metode tanam yang efektif dan efisien. Produk lain yang dihasilkan diantaranya tomat, pare, dan mangga. Setiap tanaman dibudidayakan sesuai musimnya. Budidaya cabai dilakukan saat musim hujan karena sangat membutuhkan air; sedangkan untuk tanaman sayur bisa dilakukan juga saat musim kemarau menggunakan sumber air dari sumur yang dibuat sendiri oleh para petani.

Hasil penelitian pada kelompok tani kedua disajikan pada Tabel 2.

Tabel 2.

Hasil Penelitian Pada Kelompok Tani Kedua

\begin{tabular}{|c|c|c|}
\hline \multicolumn{2}{|r|}{ Indikator } & Keterangan \\
\hline \multirow{3}{*}{$\begin{array}{l}\text { Kewirausahaan } \\
\text { dan kesempatan } \\
\text { kerja }\end{array}$} & Memanfaatkan peluang & $\begin{array}{l}\begin{array}{l}\text { menyewa lahan milik pengembang yang belum } \\
\text { digunakan }\end{array} \\
\end{array}$ \\
\hline & Memanfaatkan kemampuan & memiliki kemampuan bertani \\
\hline & Sebagai bentuk pekerjaan & sebagai bentuk pekerjaan utama \\
\hline \multirow{3}{*}{ Produksi } & $\begin{array}{l}\text { Usaha dan pemanfaatan } \\
\text { sumber daya }\end{array}$ & $\begin{array}{l}\text { usaha pertanian berupa budidaya berbagai macam } \\
\text { komoditas; memanfaatkan kemampuan dan sumber daya } \\
\text { alam yang ada }\end{array}$ \\
\hline & Produksi barang halal & komoditas tergolong halal \\
\hline & Peningkatan nilai guna & $\begin{array}{l}\text { pemanfaatan lahan menganggur untuk dijadikan lahan } \\
\text { pertanian }\end{array}$ \\
\hline \multirow{3}{*}{ Pemasaran } & Adanya proses pemasaran & $\begin{array}{l}\text { penjualan langsung kepada konsumen saat panen raya } \\
\text { dan penjualan tidak langsung kepada pengepul dan } \\
\text { pedagang }\end{array}$ \\
\hline & Implementasi prinsip kejujuran & $\begin{array}{l}\text { membedakan hasil panen yang dijual sesuai kualitasnya } \\
\text { dengan harga yang berbeda }\end{array}$ \\
\hline & Implementasi prinsip keadilan & $\begin{array}{l}\begin{array}{l}\text { menjual langsung hasil panen tanpa melakukan } \\
\text { penimbunan }\end{array} \\
\end{array}$ \\
\hline \multirow{3}{*}{ Pendapatan } & $\begin{array}{l}\text { Adanya pendapatan yang } \\
\text { diperoleh }\end{array}$ & pendapatan dari penjualan hasil panen \\
\hline & Pemenuhan kebutuhan & mampu memenuhi kebutuhan \\
\hline & Tidak terdapat riba & pendapatan tidak mengandung riba \\
\hline \multirow{2}{*}{$\begin{array}{l}\text { Kepedulian } \\
\text { sosial-ekonomi }\end{array}$} & Zakat & $\begin{array}{l}\text { tidak melaksanakan zakat pertanian } \\
\text { ketidaktaahuan }\end{array}$ \\
\hline & Kegiatan sosial & Jluhan dan pe \\
\hline
\end{tabular}

Sumber: hasil penelitian, 2016 (diolah)

\section{Kelompok Tani Ketiga}

Kelompok tani ketiga dibentuk tahun 2009 bersamaan dengan dimulainya usaha budidaya lele yang berasal dari bantuan dinas terkait. Kelompok tani ini berada di Kelurahan Pakis, Kecamatan Sawahan.

Latar belakang pembentukan kelompok tani adalah keberadaan lahan milik pengembang proyek yang masih belum digunakan dan banyaknya warga yang sudah berstatus pensiunan, maka dibentuklah kelompok tani yang berfokus pada pembudidayaan lele. Tujuan pembentukan kelompok tani ini adalah sebagai usaha pengembangan budidaya lele sekaligus untuk tambahan pendapatan bagi anggota kelompok.

Komoditas kelompok tani kedua adalah lele. Budidaya lele sengaja dipilih sebagai usaha kelompok karena relatif mudah dijalankan dan tidak terlalu membutuhkan keahlian khusus. Pembudidayaan lele dimulai dari bantuan Dinas Pertanian berupa kolam terpal sebanyak 20 kolam sekaligus bibit lele. 
Permana, et al/Jurnal Ekonomi Syariah Teori dan Terapan Vol. 3 No. 12 Desember 2016: 945-959; PERAN PERTANIAN URBAN PADA KESEJAHTERAAN PETANI MUSLIM PADA EMPAT KELOMPOK TANI DI SURABAYA DITINJAU DARI PERSPEKTIF ISLAM

Seiring perkembangan dan keberhasilan usaha, saat ini kelompok tani ini telah memiliki 60 kolam tembok dan lima lubang sumur untuk memenuhi kebutuhan air kolam saat musim kemarau.

Hasil penelitian pada kelompok tani ketiga disajikan pada Tabel 3 .

Tabel 3.

Hasil Penelitian Pada Kelompok Tani Ketiga

\begin{tabular}{|c|c|c|}
\hline \multicolumn{2}{|r|}{ Indikator } & Keterangan \\
\hline \multirow{3}{*}{$\begin{array}{l}\text { Kewirausahaan } \\
\text { dan kesempatan } \\
\text { kerja }\end{array}$} & Memanfaatkan peluang & $\begin{array}{l}\text { memanfaatkan lahan proyek yang belum digarap untuk } \\
\text { pembuatan kolam dan budidaya lele }\end{array}$ \\
\hline & Memanfaatkan kemampuan & membudidayakan lele yang relatif mudah \\
\hline & Sebagai bentuk pekerjaan & sebagai bentuk pekerjaan sampingan \\
\hline \multirow{3}{*}{ Produksi } & $\begin{array}{l}\text { Usaha dan pemanfaatan } \\
\text { sumber daya }\end{array}$ & $\begin{array}{l}\text { usaha budidaya lele yang memanfaatkan sumber daya } \\
\text { lahan dan pembuatan sumur untuk persediaan air }\end{array}$ \\
\hline & Produksi barang halal & hasil budidaya tergolong halal \\
\hline & Peningkatan nilai guna & $\begin{array}{l}\text { pemanfaatan lahan proyek yang belum digarap untuk } \\
\text { digunakan sebagai usaha budidaya lele }\end{array}$ \\
\hline \multirow{3}{*}{ Pemasaran } & Adanya proses pemasaran & $\begin{array}{l}\text { penjualan langsung kepada konsumen oleh anggota } \\
\text { pemasaran dan penjualan tidak langsung oleh anggota } \\
\text { pengembangbiak kepada anggota pemasaran }\end{array}$ \\
\hline & Implementasi prinsip kejujuran & tidak mencurangi timbangan saat terjadi transaksi \\
\hline & Implementasi prinsip keadilan & $\begin{array}{l}\text { melakukan tawar-menawar saat penjualan di pasar oleh } \\
\text { anggota pemasaran }\end{array}$ \\
\hline \multirow{3}{*}{ Pendapatan } & $\begin{array}{l}\text { Adanya pendapatan yang } \\
\text { diperoleh }\end{array}$ & $\begin{array}{l}\text { pendapatan berasal dari penjualan hasil panen lele } \\
\text { kepada anggota pemasaran maupun penjualan di pasar }\end{array}$ \\
\hline & Pemenuhan kebutuhan & $\begin{array}{l}\text { belum mampu memenuhi; hasil penjualan masih dibawah } \\
\text { nilai UMK Surabaya }\end{array}$ \\
\hline & Tidak terdapat riba & pendapatan tidak mengandung riba \\
\hline \multirow{2}{*}{$\begin{array}{l}\text { Kepedulian } \\
\text { sosial-ekonomi }\end{array}$} & Zakat & belum memenuhi syarat-syarat zakat \\
\hline & Kegiatan sosial & $\begin{array}{l}\text { pelatihan dan kunjungan kepada warga di berbagai } \\
\text { daerah mengenai budidaya perikanan }\end{array}$ \\
\hline
\end{tabular}

Sumber: hasil penelitian, 2016 (diolah)

\section{Kelompok Tani Keempat}

Kelompok tani keempat dibentuk pada tahuin 2011 dan berlokasi di Kelurahan Semolowaru, Kecamatan Sukolilo. Kelompok tani ini merupakan wadah berkumpulnya warga yang juga menjadi kader lingkungan yang mengelola lahan di belakang Balai RW. Kelompok tani ini merupakan kelompok swadaya warga yang tergabung dan tumbuh berdasarkan keakraban, keselarasan, serta kesamaan tujuan untuk meningkatkan produktivitas usaha di bidang pertanian serta usaha lainnya. Latar belakang tersebut didorong pula oleh kesadaran dalam upaya membantu program pemerintah dalam memberdayakan masyarakat sehingga dapat meningkatkan pendapatan keluarga.

Komoditas budidaya kelompok tani keempat yaitu lele, jamur, lidah buaya, dan jangkrik. Hasil budidaya keempat komoditas tersebut kemudian dijual kepada anggota kelompok untuk diolah menjadi produk-produk olahan makanan. Produk-produk olahan tersebut dijual baik secara langsung maupun melalui Sentra UKM MERR. 
Permana, et al/Jurnal Ekonomi Syariah Teori dan Terapan Vol. 3 No. 12 Desember 2016: 945-959; PERAN PERTANIAN URBAN PADA KESEJAHTERAAN PETANI MUSLIM PADA EMPAT KELOMPOK TANI DI SURABAYA DITINJAU DARI PERSPEKTIF ISLAM

Hasil penelitian pada kelompok tani keempat disajikan pada Tabel 4.

Tabel 4.

Hasil Penelitian Pada Kelompok Tani Keempat

\begin{tabular}{|c|c|c|}
\hline \multicolumn{2}{|r|}{ Indikator } & Keterangan \\
\hline \multirow{3}{*}{$\begin{array}{l}\text { Kewirausahaan } \\
\text { dan kesempatan } \\
\text { kerja }\end{array}$} & Memanfaatkan peluang & $\begin{array}{l}\text { menggunakan lahan fasilitas umum dan bantuan-bantuan } \\
\text { yang telah didapat }\end{array}$ \\
\hline & Memanfaatkan kemampuan & $\begin{array}{l}\text { kemampuan membudidayakan beragam komoditas serta } \\
\text { mengolah hasilnya menjadi produk olahan }\end{array}$ \\
\hline & Sebagai bentuk pekerjaan & sebagai bentuk pekerjaan sampingan \\
\hline \multirow{3}{*}{ Produksi } & $\begin{array}{l}\text { Usaha dan pemanfaatan } \\
\text { sumber daya }\end{array}$ & $\begin{array}{l}\text { usaha budidaya yang memanfaatkan lahan fasilitas } \\
\text { umum dan pengolahan produk hasil budidaya }\end{array}$ \\
\hline & Produksi barang halal & hasil budidaya dan produk olahannya tergolong halal \\
\hline & Peningkatan nilai guna & $\begin{array}{l}\text { pemanfaatan lahan fasilitas umum untuk kegiatan } \\
\text { budidaya yang produktif dan mengolah hasilnya untuk } \\
\text { meningkatkan nilai jual }\end{array}$ \\
\hline \multirow{3}{*}{ Pemasaran } & Adanya proses pemasaran & $\begin{array}{l}\text { penjualan langsung kepada konsumen dan penjualan } \\
\text { tidak langsung melalui Sentra UKM MERR }\end{array}$ \\
\hline & Implementasi prinsip kejujuran & mencantumkan informasi komposisi produk olahan \\
\hline & Implementasi prinsip keadilan & harga jual sesuai harga pasar \\
\hline \multirow{3}{*}{ Pendapatan } & $\begin{array}{l}\text { Adanya pendapatan yang } \\
\text { diperoleh }\end{array}$ & $\begin{array}{l}\text { Pendapatan anggota berasal dari penjualan produk } \\
\text { olahan }\end{array}$ \\
\hline & Pemenuhan kebutuhan & $\begin{array}{l}\text { belum mampu memenuhi; hasil penjualan produk olahan } \\
\text { masih dibawah nilai UMK Surabaya }\end{array}$ \\
\hline & Tidak terdapat riba & $\begin{array}{l}\text { pendapatan dari penjualan produk olahan tidak } \\
\text { mengandung riba; pendapatan unit usaha simpan-pinjam } \\
\text { mengandung riba }\end{array}$ \\
\hline \multirow{2}{*}{$\begin{array}{l}\text { Kepedulian } \\
\text { sosial-ekonomi }\end{array}$} & Zakat & belum memenuhi syarat-syarat zakat \\
\hline & Kegiatan sosial & pelatihan di berbagai tempat \\
\hline
\end{tabular}

Sumber: hasil penelitian, 2016 (diolah)

\section{Kesejahteraan Materi}

Keempat kelompok tani berhasil memanfaatkan peluang dan kemampuan yang dimiliki anggotanya, seperti pemberdayaan warga lansia dan pensiunan, penggunaan lahan menganggur untuk kegiatan budidaya yang produktif, dan kemampuan mengolah hasil budidaya menjadi berbagai macam produk olahan. Hal tersebut menandakan bahwa kegiatan pertanian urban mampu dimanfaatkan oleh kelompok tani dengan potensi masing-masing sehingga membuka kesempatan kerja dan peluang wirausaha bagi anggota kelompok.
Islam mewajibkan manusia untuk bekerja demi memenuhi kebutuhan hidup. Bekerja juga merupakan sebuah bentuk ibadah karena dengan bekerja maka manusia akan mendapat karunia Allah SWT. Alquran menjelaskan tentang kewajiban manusia untuk bekerja, diantaranya pada Surat Al-Jumu'ah:10 berikut.

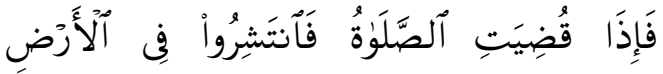

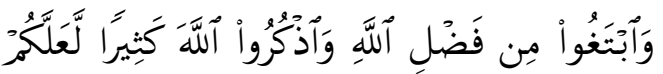

$$
\begin{aligned}
& \text { تُفْلِحُونَ تَفِ }
\end{aligned}
$$

Artinya: "10. Apabila telah ditunaikan sembahyang, maka bertebaranlah kamu di bumi; dan carilah karunia Allah dan ingatlah Allah banyakbanyak supaya kamu beruntung." 
Permana, et al/Jurnal Ekonomi Syariah Teori dan Terapan Vol. 3 No. 12 Desember 2016: 945-959; PERAN PERTANIAN URBAN PADA KESEJAHTERAAN PETANI MUSLIM PADA EMPAT KELOMPOK TANI DI SURABAYA DITINJAU DARI PERSPEKTIF ISLAM

$$
\begin{aligned}
& \text { (QS Al-Jumu'ah:10) (Kemenag, } \\
& \text { 2009:933). } \\
& \text { Lebih lanjut, anggota keempat }
\end{aligned}
$$

kelompok tani mampu memroduksi hasil komoditas budidaya masing-masing. Kelompok tani pertama dan kelompok tani kedua juga mengolah hasil budidaya menjadi berbagai macam produk olahan. Produksi dalam Alquran dijelaskan salah satunya pada Surat Al-Hijr:19-20. Ayat ini menjelaskan bahwa Allah SWT menciptakan sumber daya di bumi sebagai sumber kehidupan setiap makhluk-Nya termasuk manusia agar dapat memenuhi kebutuhan dengan melakukan produksi barang-barang kebutuhan.

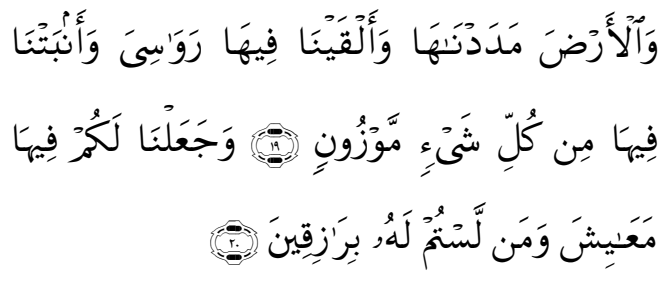

Artinya: "19. Dan Kami telah menghamparkan bumi dan Kami menjadikan padanya gununggunung dan Kami tumbuhkan padanya segala sesuatu menurut ukuran. 20. Dan Kami telah menjadikan untukmu keperluankeperluan hidup, dan (Kami menciptakan pula) makhluk-makhluk yang kamu sekali-kali bukan pemberi rezki kepadanya." (QS Hijr:19-20) (Kemenag, 2009:392).

Keempat kelompok tani juga memasarkan hasil produksinya baik secara langsung kepada konsumen maupun secara tidak langsung melalui pedagang, pengepul, dan penitipan. Artinya, terdapat kegiatan penjualan hasil produksi yang dilakukan oleh keempat kelompok tani. Alquran menjelaskan tentang jual-beli pada Surat An-Nisaa':29.

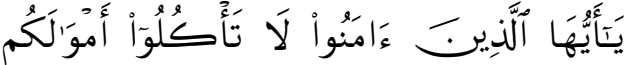

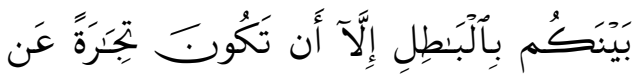

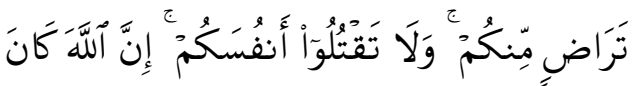

$$
\begin{aligned}
& \text { بِكُمْ رَحِيمَّا }
\end{aligned}
$$

Artinya: "29. Hai orang-orang yang beriman, janganlah kamu memakan harta sesamamu dengan jalan yang batil, kecuali dengan jalan perniagaan yang berlaku dengan suka sama suka di antara kamu. Dan janganlah kamu membunuh dirimu; sesungguhnya Allah adalah Maha Penyayang Kepadamu." (QS AnNisaa':29) (Kemenag, 2009:122).

Berdasarkan hal tersebut, maka kegiatan pertanian urban berperan terhadap terbentuknya usaha kecil pada sektor pertanian dan sektor informal. Definisi usaha kecil menurut UndangUndang No. 9 tahun 1995 tentang Usaha Kecil adalah kegiatan ekonomi rakyat yang memiliki hasil penjualan tahunan maksimal Rp 1.000.000.000,00 dan memiliki kekayaan bersih, tidak termasuk tanah dan bangunan tempat usaha, paling banyak Rp 200.000.000,00.

Anggota keempat kelompok tani juga diketahui memperoleh pendapatan dari kegiatan pertanian urban yang dijalankan. Anggota kelompok tani kedua mampu memenuhi kebutuhan keluraga karena kegiatan pertanian urban yang dilakukan merupakan pekerjaan utama; sedangkan anggota ketiga kelompok tani lainnya memperoleh pendapatan tetapi masih dibawah nilai UMK Kota Surabaya. 
Permana, et al/Jurnal Ekonomi Syariah Teori dan Terapan Vol. 3 No. 12 Desember 2016: 945-959; PERAN PERTANIAN URBAN PADA KESEJAHTERAAN PETANI MUSLIM PADA EMPAT KELOMPOK TANI DI SURABAYA DITINJAU DARI PERSPEKTIF ISLAM

Jadi, kegiatan pertanian urban juga berperan meningkatkan pendapatan anggota keempat kelompok tani.

\section{Kesejahteraan Non Materi}

Kesejahteraan non materi terkait aspek kesesuain perilaku ekonomi keempat kelompok tani dengan syariat Islam yang bercirikan: setia dan taat kepada Allah SWT (habl min Allah), setia dan konsisten memberikan manfaat atau pelayanan terbaik kepada sesama manusia (habl min al-nās), dan setia dan konsisten dengan pemelihara alam dan lingkungan yang seimbang (habl min al'ālaminn). Pembahasan terkait kesesuaian kegiatan pertanian urban dengan syariat Islam dapat dilihat pada lingkup produksi, pemasaran, pendapatan, dan kepedulian sosial-ekonomi.

Pada lingkup produksi, keempat kelompok tani menghasilkan komoditaas hasil budidaya dan produk-produk olahan yang tergolong halal sehingga menjaga ketaatan kepada Allah SWT (habl min Allah). Alquran menekankan pentingnya kehalalan seperti yang tercantum pada beberapa ayat, diantaranya pada Surat Al-Mu'minun:51 sebagai berikut.

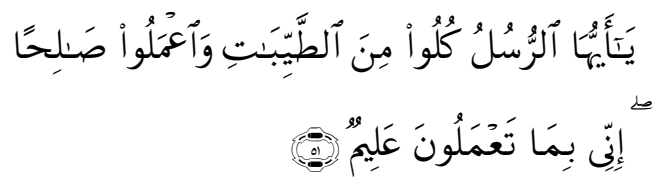

Artinya: "51. Hai rasul-rasul, makanlah dari makanan yang baikbaik, dan kerjakanlah amal yang saleh. Sesungguhnya Aku Maha Mengetahui apa yang kamu kerjakan." (QS Al-Mu'minun:51) (Kemenag, 2009:532).
Pada lingkup pemasaran, keempat kelompok tani mengimplementasikan prinsip kejujuran dan prinsip keadilan sesuai kondisi dan situasi masing-masing kelompok tani sehingga memberikan manfaat atau pelayanan terbaik kepada sesama manusia (habl min al-nās). Karim (2012:153) mengatakan "Islam mengatur agar persaingan di pasar dilakukan dengan adil. Setiap bentuk yang dapat menimbulkan ketidakadilan dilarang".

Pada lingkup pendapatan dari penjualan hasil budidaya maupun produk olahan, keempat kelompok tani diketahui menerima pendapatan yang tidak mengandung riba sehingga menjaga ketaatan kepada Allah SWT (habl min Allah) serta memberikan manfaat atau pelayanan terbaik kepada sesama manusia (habl min al-nās). Riba secara jelas dilarang oleh Allah SWT seperti yang dijelaskan dalam Surat Al-Baqarah 275-276 berikut.

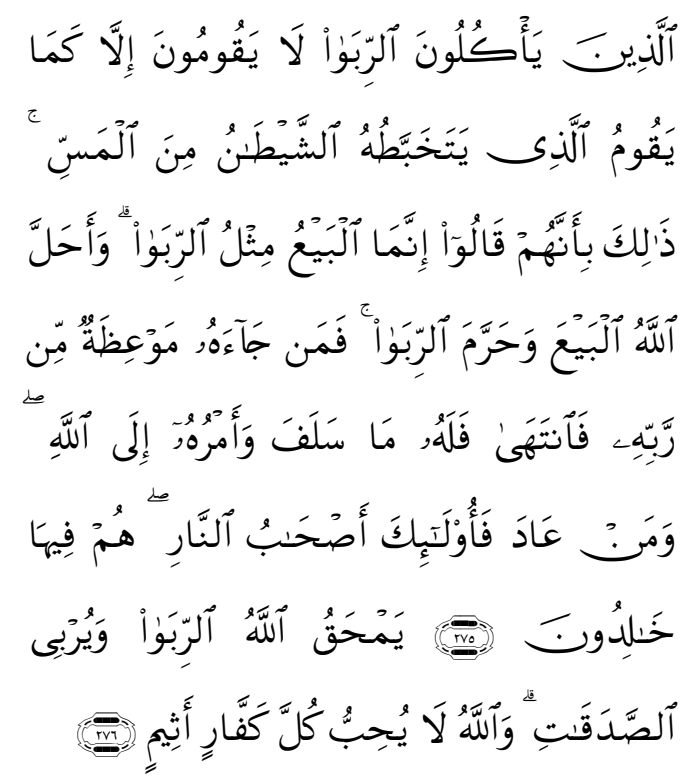


Permana, et al/Jurnal Ekonomi Syariah Teori dan Terapan Vol. 3 No. 12 Desember 2016: 945-959; PERAN PERTANIAN URBAN PADA KESEJAHTERAAN PETANI MUSLIM PADA EMPAT KELOMPOK TANI DI SURABAYA DITINJAU DARI PERSPEKTIF ISLAM

Artinya: "275. Orang-orang yang makan (mengambil riba) tidak dapat berdiri melainkan seperti berdirinya orang yang kemasukan syaitan lantaran (tekanan) penyakit gila. Keadaan mereka yang demikian itu, adalah disebabkan mereka berkata (berpendapat), sesungguhnyajual beli itu sama dengan riba, padahal Allah telah menghalalkan jual beli dan mengharamkan riba. Orangorang yang telah sampai kepadanya larangan dari Tuhannya, lalu terus berhenti (dari mengambil riba), maka baginya apa yang telah diambilnya dahulu (sebelum datang larangan), dan urusannya (terserah) kepada Allah. Orang yang mengulangi (mengambil riba), maka orang itu adalah penghuni-penghuni neraka; mereka kekal di dalamnya. 276. Allah memusnahkan riba dan menyuburkan sedekah. Dan Allah tidak menyukai setiap orang yang tetap dalam kekafiran, dan dan selalu berbuat dosa." (QS Al-Baqarah:275-276) (Kemenag, 2009:69).

Pada lingkup kepedulian sosialekonomi, keempat kelompok tani diketahui melakukan kegiatan pemberdayaan masyarakat seperti penyuluhan dan pelatihan kepada masyarakat yang membutuhkan sehingga memberikan manfaat atau pelayanan terbaik kepada sesama manusia (habl min al-nās). Alquran menjelaskan pentingnya kepedulian terhadap sesama manusia dalam bentuk saling tolong menolong seperti yang dijelaskan pada Surat AlMaidah:2 berikut.

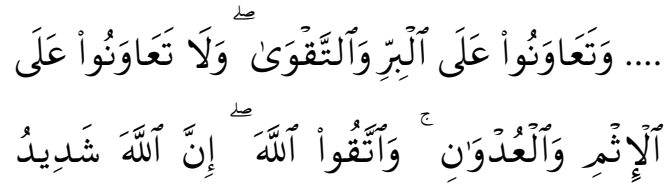

Artinya: "2. .... Dan tolong menolonglah kamu dalam (mengerjakan) kebajikan dan takwa, dan jangan tolong-menolong dalam berbuat dosa dan pelanggaran. Dan bertakwalah kamu kepada Allah, sesungguhnya Allah amat berat siksaNya." (QS AL-Maidah:2) (Kemenag, 2009:157).

\section{SIMPULAN}

Simpulan yang dapat diambil dari hasil penelitian mengenai peran pertanian urban pada kesejahteraan petani muslim pada empat kelompok tani di Surabaya ditinjau dari perspektif Islam yaitu:

1. Kesejahteraan materi

a. Menciptakan kesempatan kerja dan wirausaha baik dalam bidang pertanian maupun bidang pengolahan.

b. Menciptakan usaha kecil pada sektor pertanian dan sektor informal.

c. Meningkatkan pendapatan anggota keempat kelompok tani.

2. Kesejahteraan non materi Menjaga ketaatan kepada Allah SWT (habl min Allah) dan memberikan manfaat atau pelayanan terbaik kepada sesama manusia (habl min al-nās) yaitu:

a. Menghasilkan komoditas hasil budidaya dan produk-produk olahan yang tergolong halal.

b. Menghasilkan pendapatan yang tidak mengandung riba.

c. Mewujudkan kejujuran dan keadilan dalam pemasaran. 
Permana, et al/Jurnal Ekonomi Syariah Teori dan Terapan Vol. 3 No. 12 Desember 2016: 945-959; PERAN PERTANIAN URBAN PADA KESEJAHTERAAN PETANI MUSLIM PADA EMPAT KELOMPOK TANI DI SURABAYA DITINJAU DARI PERSPEKTIF ISLAM

$$
\begin{aligned}
& \text { d. Mendorong kegiatan } \\
& \text { pemberdayaan masyaraka } \\
& \text { seperti penyuluhan dan pelatihan. }
\end{aligned}
$$

\section{DAFTAR PUSTAKA}

Aedy, Hasan. 2011. Teori dan Aplikasi Ekonomi Pembangunan Perspektif Islam Sebuah Studi Komparasi. Yogyakarta: Graha llmu.

Anto, M. B. Hendrie. 2003. Pengantar Ekonomika Mikro Islami. Yogyakarta: Ekonisia.

Arsyad, Sitanala. 1989. Konservasi Tanah dan Air. Bogor: IPB.

Karim, Adiwarman. 2012. Ekonomi Mikro Islami. Jakarta: PT. Raja Grafindo Persada.

Kaufman, Jerry dan Martin Bailkey. 2000. Farming Inside Cities: Entrepreneurial Urban Agriculture in the United States. Working Paper. Massachusetts: Lincoln Institute of Land Policy.

Kementerian Urusan Agama Islam, Wakaf, Dakwah, dan Bimbingan Islam Kerajaan Arab Saudi. 2009. Alqur'an dan Terjemahnya. Madinah: Mujamma' Al Malik Fahd Li Tibha'at Al Mush-haf Asy Syarif.

Musa, Marwan bin. 2013. Ilmu Fikih Ihyaa'ul Mawat (Menghidupkan Tanah Yang Mati) (Bag. 1), (Online), (http://yufidia.com/ilmu-fikih-ihyaaulmawat-menghidupkan-tanah-yangmati-bag-1, diakses pada 22 September 2015).

Primartantyo, Ukky. 2011. Masih Ada Lahan 150 Kali Luas Singapura 'Nganggur'. Tempo, (Online), (http://nasional.tempo.co/read/news /2011/ 12/06/078370137/masih-adalahan-150-kali-luas-singapura-

nganggur, diakses pada 22 September 2015).

Purbaya, Ahmad Ghofar. 2015. Strategi Peningkatan Jesejahteraan Ekonomi Masyarakat Pengusaha Kerupuk dan Camilan Hasil Laut di Pantai Kenjeran Lama Surabaya. Skripsi tidak diterbitkan. Surabaya: UIN Sunan Ampel.

Purwana, Agung Eko. 2014. Kesejahteraan Dalam Perspektif Ekonomi Islam. Justicia Islamica, 2014, 11 (1). Ponorogo: STAIN Ponorogo.
Republik Indonesia. Undang-Undang No.9 Tahun 1995 Tentang: Usaha Kecil. Jakarta: Presiden Republik Indonesia.

Santoso, Eko Budi dan Rini Ratna Widya. 2014. Gerakan Pertanian Perkotaan Dalam Mendukung Kemandirian Masyarakat Di Kota Surabaya. Dalam Seminar Nasional Cities 2014. Surabaya: Institut Teknologi Sepuluh November.

Siswanto, Siswanto. 2006. Evaluasi Sumber daya Lahan. Surabaya: UPN Press.

Smit, Jack dkk. 2001. Cities That Feed Themselves. Dalam Smit, Jack dkk. 2001. Urban Agriculture: Food, Jobs and Sustainable Cities. New York: The Urban Agriculture Network, Inc.

Veenhuizen, René van dan George Danso. 2007. Profitability and sustainability of urban and peri-urban agriculture. Rome: FAO.

Yin, Robert K. 2009. Case Study Research Design and Methods. Fourth Edition. California: Sage Inc. 